\title{
Evaluasi program pendidikan kewirausahaan masyarakat
}

\author{
Arif Wijayanto *, Iis Prasetyo \\ Program Studi Pendidikan Luar Sekolah, Program Pascasarjana, Universitas Negeri Yogyakarta, \\ Jalan Colombo No. 1, Karangmalang, 55281, Yogyakarta, Indonesia. \\ * Corresponding Author. Email: arifkardi@gmail.com \\ Received: 24 July 2017; Revised: 31 October 2018; Accepted: 3 December 2018
}

\begin{abstract}
Abstrak
Penelitian ini bertujuan untuk menganalisis: (1) dampak jangka panjang (2) outcome (3) output (4) proses (5) input program PKM di Kabupaten Sleman. Penelitian ini merupakan penelitian evaluasi yang merujuk pada model Logical Framework dengan jenis penelitian kualitatif. Pendekatan evaluasi disusun secara sistematis meliputi evaluasi (a) dampak jangka panjang program, (b) outcome program, (c) output program, (d) proses program, dan (e) input program. Data penelitian dikumpulkan melalui observasi, wawancara dan dokumentasi. Teknik analisis data dilakukan dengan model interaktif. Adapun langkahnya yaitu pengumpulan data, reduksi data, penyajian data, dan verifikasi dan penarikan kesimpulan. Hasil penelitian mengenai evaluasi program PKM di Kabupaten Sleman adalah sebagai berikut (1) Dampak jangka panjang dicapai oleh LKP Silia dan LKP Macell EC; (2) Outcome dicapai oleh LKP Silia, namun tidak dicapai oleh LKP Macell EC; (3) Output dicapai oleh LKP Silia, namun tidak dicapai oleh LKP Macell EC; (4) Proses dicapai oleh LKP Silia, namun tidak dicapai oleh LKP Macel karena penggunaan media di LKP Macell EC kurang maksimal dan kurang mendukung proses pembelajaran; (5) Input yang sesuai dengan prasyarat program telah dicapai oleh LKP Silia, namun tidak berhasil dicapai oleh LKP Macell EC terutama pada prasyarat tutor dan media pembelajaran.
\end{abstract}

Kata Kunci: evaluasi, program, pendidikan kewirausahaan masyarakat

\section{Evaluation of community entrepreneurship education program}

\begin{abstract}
This study aims to analyze: (1) long-term impact (2) outcome (3) output (4) process (5) input PKM program in Sleman District. This research is an evaluation research that refers to Logical Framework model with qualitative research type. The evaluation approach is systematically composed including evaluation of (a) the program's long-term impact, (b) program outcomes, (c) program outputs, (d) program processes, and (e) program inputs. The research data was collected through observation, interview and documentation. Data analysis was done by interactive model. The steps are data collection, data reduction, data presentation, and verification and conclusion. The results of research on evaluation of PKM program in Sleman District are as follows (1) long term impact achieved by LKP Silia and LKP Macell EC; (2) Outcome achieved by LKP Silia, but not achieved by LKP Macell EC; (3) Output was achieved by LKP Silia, but not achieved by LKP Macell EC; (4) Process is achieved by LKP Silia, but not reached by LKP Macell EC; (5) Input is achieved or in accordance with the criteria of success by LKP Silia, but on LKP Macell EC.
\end{abstract}

Keywords: evaluation, program, enterpreneurship education community

How to Cite: Wijayanto, A., \& Prasetyo, I. (2018). Evaluasi program pendidikan kewirausahaan masyarakat. JPPM (Jurnal Pendidikan dan Pemberdayaan Masyarakat), 5(2), 96-107. doi:https://doi.org/10.21831/jppm.v5i2.14999

doi) https://doi.org/10.21831/jppm.v5i2.14999 


\section{JPPM (Jurnal Pendidikan dan Pemberdayaan Masyarakat), 5 (2), 2018 - 97 \\ Arif Wijayanto, Iis Prasetyo}

\section{PENDAHULUAN}

Upaya pemerintah Daerah Istimewa Yogyakarta (DIY) dalam mengurangi jumlah pengangguran terus dilaksanakan. Data BPS Provinsi DIY menunjukkan Tingkat Pengangguran Terbuka (TPT) dari bulan Februari 2014-Februari 2016 berada dalam kisaran 2,74,1 persen dan fluktuatif. Pada bulan Februari 2016 TPT DIY mencapai 2,81 persen, mengalami penurunan 1,26 poin dibanding TPT Februari 2015 sebesar 4,07 persen. Angka ini lebih rendah dibanding TPT Nasional sebesar 5,50 persen pada Februari 2016 (Badan Pusat Statistik Daerah Istimewa Yogyakarta, 2016, p.1). Data ini menunjukkan bahwa jumlah pengangguran di DIY berkurang dan berada pada posisi yang baik pada tingkat nasional.

Diharapkan dari tahun ke tahun jumlah pengangguran di DIY semakin berkurang. Terutama daerah-daerah yang memiliki jumlah pengangguran terbesar di DIY. Dilihat dari Badan Pusat Statistik (BPS) DIY, persebaran angka pengangguran di DIY yang terbesar ada di Kabupaten Sleman, yang mencapai 19.406 orang, disusul Bantul 16.632 orang, Kota Yogyakarta 13.702 orang, Gunungkidul 7.385 orang dan Kulonprogo 6.764 orang (Badan Pusat Statistik Daerah Istimewa Yogyakarta, 2016, p.1). Selain berorientasi mengurangi jumlah pengangguran, sumber daya manusia (SDM) yang masih belum terpakai itu juga perlu dipersiapkan untuk bersaing menghadapi Masyarakat Ekonomi ASEAN (MEA), dimana tenaga kerja dari luar negeri akan turut bersaing di dalam negeri.

Kewirausahaan menempati tempat yang penting dalam ekonomi modern, karena kewirausahaan merupakan sumber utama untuk melawan pengangguran (Khalifa \& Diaf, 2016, p.120). Kewirausahaan dapat menjadi solusi bagi pengangguran, hal ini dilihat dari relatif banyaknya tulisan mengenai kewirausahaan yang berpotensi menciptakan lapangan kerja (Anyadike, 2012, p.88). Melalui pengembangan keterampilan berwirausaha, menjadi cara mengurangi jumlah pengangguran, menciptakan lapangan kerja, mengentaskan masyarakat dari kemiskinan dan keterpurukan ekonomi. Lebih jauh lagi secara politik, meningkatkan harkat sebagai bangsa yang mandiri dan bermartabat. Jiwa kewirausahaan merupakan modal utama dari keberlanjutan program dimana warga belajar dituntut untuk dapat menerapkan hasil pelatihan dalam kehidupan mereka seharihari dengan memanfaatkan materi pelatihan yang mereka peroleh untuk kegiatan usaha.

Program-program kewirausahaan bagi masyarakat yang tidak memiliki pekerjaan merupakan salah satu alternatif yang dapat dilakukan untuk mengurangi jumlah pengangguran di suatu daerah. Bertambahnya jumlah wirausahawan dalam suatu daerah atau negara akan mempengaruhi tingkat kemakmuran warganya. Sesuai dengan pendapat dari David Mike Dallen seorang ahli ekonomi yang menyatakan bahwa suatu negara baru menjadi makmur bila jumlah wirausahawannya paling sedikit dua persen dari jumlah penduduknya (Prasetyo, 2011, p.1).

Proses pendidikan dipandang terobosan yang baik dalam membangun wirausahawan didalam masyarakat (Sabri, 2013, p.26). Menggalakkan budaya kewirausahaan dalam masyarakat akan mampu membuka lapangan pekerjaan sehingga penggangguran dan kemiskinan dapat dihindari. Diharapkan nantinya, masyarakat akan menjadi sumber daya manusia yang tangguh, apabila bekerja di perusahaan akan menjadi tenaga kerja yang mandiri, dan apabila tidak bekerja di perusahaan akan menjadi manusia yang mampu menciptakan lapangan pekerjaan, minimal bagi dirinya sendiri.

Pendidikan kewirausahaan memang sangat penting untuk menumbuhkan niat berwirausaha bagi masyarakat. Beberapa peluang sebagai keuntungan seseorang berwirausaha adalah (1) mempunyai kebebasan mencapai tujuan yang dikehendaki, (2) mempunyai kesempatan untuk menunjukan kemampuan dan potensi diri secara penuh, (3) memperoleh manfaat dan laba yang maksimal, (4) terbuka kesempatan untuk melakukan perubahan, (5) terbuka peluang untuk berperan dalam masyarakat dan mendapatkan pengakuan atas usaha mereka (Suharyadi, Purwanto, \& Maman, 2007, p.8). Kewiraushaan juga mencerminkan kualitas dan kemampuan seseorang dalam menghadapi tantangan dan resiko, memanfaatkan 


\section{JPPM (Jurnal Pendidikan dan Pemberdayaan Masyarakat), 5 (2), 2018 - 98}

Arif Wijayanto, Iis Prasetyo

peluang, dan mencapai keberasilan. Jiwa kewirausahaan itu sendiri bukanlah jaminan keberasilan suatu kegiatan (bisnis), namun sering kali menjadi prasyarat yang harus dipenuhi, lebih dari itu kewirausahaan juga dipandang sebagai kemampuan seseorang dalam menghadapi lingkungannya, yang ditunjukan oleh serangkaian sikap dan perilaku (Suparta \& Ramantha, 2010, p.2).

Pada tahun 2010 Direktorat Jenderal Pendidikan Nonformal dan Informal merintis program Pendidikan Kewirausahaan Masyarakat (PKM) yakni program pendidikan non formal yang didalamnya terdapat pendidikan kewirausahaan (pendidikan karakter berwirausaha bagi peserta didik) dan pendidikan vokasional (keterampilan) yang selanjutnya lulusan dari program tersebut ditindaklanjuti dengan berbagai Kementerian, Instansi, Lembaga dan Organisasi terkait untuk merintis usaha kecil sebagai wirausahawan. Misi dan tujuan dari pendidikan ini adalah memberikan bekal pendidikan yang bermutu dan relevan dengan kebutuhan masyarakat sehingga setiap lulusan pendidikan non formal dapat masuk di dunia kerja dan atau menciptakan lapangan kerja baru, menghasilkan produk barang dan/atau jasa yang kreatif dan inovatif sehingga mampu memberdayakan potensi lokal untuk meningkatkan kualitas hidup masyarakat.

Pendidikan Kewirausahaan Masyarakat (PKM) adalah program pelayanan pendidikan kewirausahaan dan keterampilan usaha yang diselenggarakan oleh lembaga kursus dan pelatihan (LKP), atau satuan PNF lainnya dan organisasi kemasyarakatan atau organisasi sosial yang menyelenggarakan program pendidikan dan pelatihan disesuaikan dengan kebutuhan dan peluang usaha yang ada di masyarakat (Kementerian Pendidikan dan Kebudayaan Republik Indonesia, 2014, p.7). Biaya yang diperlukan dalam melaksanakan pelatihan sepenuhnya ditanggung oleh pemerintah. Penyelenggaraan program pendidikan kewirausahaan ini dirancang guna menyediakan hasil pendidikan berupa sumber daya manusia yang mampu berdaya saing, dan terampil dalam mencari dan memanfaatkan peluang usaha di lingkungan yang kompetitif. Pada akhirnya program ini dapat mendukung terhadap efektifitas pencapaian tujuan pembelajaran sebagai bentuk nyata dari dampak pelatihan yang diharapkan dan ditetapkan sebelumnya.

Dalam hal ini, pendidikan non formal khususnya lembaga kursus dan pelatihan, dipandang sangat efektif untuk membantu mengatasi berbagai permasalahan kemiskinan dan pengangguran yang terjadi di Kabupaten Sleman. Kehadiran pendidikan non formal dalam ikut mencerdaskan bangsa sangat diperlukan, peningkatan mutu pendidik dan tenaga kependidikan non formal adalah sebagai keharusan karena terkait dengan konsep dasar pendidikan sepanjang hayat (Septiarti \& Mulyadi, 2007, pp.21-27). Pendidikan non formal mempunyai sumbangan yang berarti bagi peningkatan kualitas hidup manusia, karena tidak semua warga masyarakat dapat menikmati pendidikan persekolahan. Mereka yang tidak berkesempatan mengikuti pendidikan sekolah dapat menempuh jalur pendidikan luar sekolah. Oleh karena itu, pendidikan luar sekolah tidak dapat dipandang dengan sebelah mata karena telah terbukti sangat besar kontribusinya dalam pembangunan di bidang pendidikan dalam sistem pendidikan nasional.

Kursus dan pelatihan dipandang sebagai upaya yang dapat membantu masyarakat dalam meningkatkan kualitas mulai dari pengetahuan, keterampilan dan sikap. Dalam Undang-Undang Nomor 20 tahun 2003 pasal 26 ayat 5, berbunyi "Kursus dan pelatihan diselenggarakan bagi masyarakat yang memerlukan bekal pengetahuan, keterampilan, kecakapan hidup, dan sikap untuk mengembangkan diri, mengembangkan profesi, bekerja, usaha mandiri, dan /atau melanjutkan pendidikan ke jenjang yang lebih tinggi" (Presiden Republik Indonesia, 2003). Lembaga kursus secara tidak langsung sangat membantu dalam peningkatan motivasi dan kemandirian seseorang dalam dunia pekerjaan ataupun mengembangkan kemampuannya dalam berwirausaha. Keterampilan berwirausaha diberikan untuk mempersiapkan peserta didik menjadi wirausahawan setelah lulus dari kursus atau pelatihan. Bekal pendidikan kewirausahaan ini dapat digunakan untuk memperoleh penghasilan dan pada akhirnya mencapai kesejahteraan yang diharapkan. 


\section{JPPM (Jurnal Pendidikan dan Pemberdayaan Masyarakat), 5 (2), 2018 - 99}

Arif Wijayanto, Iis Prasetyo

Salah satu bentuk pelaksanaan program pendidikan kewirausahaan masyarakat (PKM) dalam pendidikan non formal adalah melalui Lembaga Kursus dan Pelatihan (LKP). Program pendidikan kewirausahaan masyarakat ini telah dilaksanakan oleh beberapa LKP di seluruh wilayah Kabupaten Sleman. Dalam hal ini ditemukan permasalahan bahwa program pendidikan kewirausahaan masyarakat (PKM) yang diterapkan untuk mengatasi permasalahan kurangnya tenaga terdidik, belum memperlihatkan dampak jangka panjang, dampak jangka menengah, dan keluaran program yang jelas. Selain itu juga belum diketahui bagaimana sebenarnya proses pelaksanaan program PKM di Kabupaten Sleman. Padahal program PKM telah dilaksanakan selama enam tahun berturut-turut sejak tahun 2010.

Melalui evaluasi, diharapkan mampu menemukan masalah-masalah yang ada dalam program pendidikan kewirausahaan masyarakat. Evaluasi program ini sangat penting, karena dapat dijadikan pertimbangan bagi pemerintah terhadap keberlangsungan program. Ada dua jenis evaluasi yang harus diketahui yaitu evaluasi formatif dan evaluasi sumatif. Menurut Scriven (McDavid, Huse, \& Hawthorn, 2018) evaluasi formatif dimaksudkan untuk memberikan umpan balik dan saran dengan niat memperbaiki program, sedangkan evaluasi sumatif berkaitan dengan apakah program telah mencapai tujuan yang telah ditetapkan. Evaluasi program yang telah terlaksana (ex-post), sangat tepat untuk melihat tingkat keberhasilan atau kegagalan sebuah program (Zidane, Johansen, Hussein, \& Andersen, 2016, p. 26). Program kewirausahaan masyarakat yang akan diteliti telah berlangsung sehingga peneliti ingin melihat apakah program tersebut telah mencapai tujuan. Oleh karena itu, evaluasi yang digunakan dalam penelitian ini merupakan evaluasi ex-post.

Dalam hal ini, LKP Silia dan LKP Macell Education Centre yang merupakan Lembaga Kursus dan Pelatihan di Kabupaten Sleman memenuhi kriteria tersebut. Kedua lembaga ini telah melaksanakan Program Kewirausahaan Masyarakat dalam tiga tahun terakhir, sejak tahun 2014. Bidang kursus dan pelatihan di masing-masing LKP tersebut berbeda. Kedua LKP ini juga telah resmi terakreditasi oleh BAN PNF. Kedua LKP tersebut terbilang berhasil dalam melaksanakan program pendidikan kewirausahaan masyarakat di Kabupaten Sleman. Hal tersebut ditunjukkan dengan tercapainya kriteria keberhasilan program yang dapat terlihat dari laporan hasil pelaksanaan program PKM. Kriteria keberhasilan tersebut diantaranya: (1) minimal 90\% dari jumlah peserta didik dapat menyelesaikan program pelatihan dengan tuntas, (2) Minimal $65 \%$ dari peserta didik yang lulus program PKM dapat merintis usaha, (3) Adanya laporan penyelenggaraan program dan keuangan Program PKM, (4) Kecepatan dan ketepatan dana Program Bantuan PKM yang diakses oleh lembaga penyelenggara.

Berdasarkan permasalahan yang ada, penulis merasa perlu untuk melakukan penelitian mengenai evaluasi program pendidikan kewirausahaan masyarakat (PKM) di Kabupaten Sleman. Oleh karena itu, penelitian ini dipilih dengan asumsi agar dapat mengetahui dan melihat dampak jangka panjang dari program pendidikan kewirausahaan masyarakat tersebut.

\section{METODE}

Penelitian ini merupakan penelitian terhadap program Pendidikan Kewirausahaan Masyarakat (PKM) pada dua LKP di Kabupaten Sleman. Penelitian evaluasi ini bermaksud menjelaskan mengenai program PKM, mulai dari dampak jangka panjang, outcome, output, proses dan input dari program. Informasi-informasi tersebut kemudian dievaluasi melalui prosedur alamiah serta logis untuk dianalisis dan ditentukan manfaat dari suatu program PKM

Waktu penelitian dilaksanakan pada bulan Januari 2017 sampai Maret 2017. Pelaksanaan pengumpulan data dilakukan di LKP Silia dan LKP Macell EC yang keduanya berlokasi di Kabupaten Sleman. Penelitian ini dilaksanakan di dua tempat, yaitu: LKP SILIA, Jalan Tantular Selatan no 414B, Pringwulung, Condongcatur Depok Sleman dan LKP Macell Education Centre, Jalan Kaliurang km 4,5 no ${ }_{5} \mathrm{C}$, Depok Sleman.

Subjek dalam penelitian ini adalah penyelenggara, fasilitator (tutor), dan peserta program tersebut. Sumber data dari penye- 


\section{JPPM (Jurnal Pendidikan dan Pemberdayaan Masyarakat), 5 (2), 2018 - 100 \\ Arif Wijayanto, Iis Prasetyo}

lenggara program adalah kepala LKP Silia dan kepala LKP Macell EC. Sumber data ini guna untuk mengetahui informasi mengenai program pendidikan kewirausahaan masyarakat. Selain itu, sumber data lainnya yaitu fasilitator, dan peserta program pendidikan kewirausahaan masyarakat juga digali untuk mengetahui pelaksanaan, proses, dan hasil program tersebut. Maksud dari pemilihan subyek ini adalah untuk mendapatkan sebanyak mungkin informasi dari sumber yang berbeda sehingga data yang diperoleh dapat diakui kebenarannya

Instrumen utama dalam penelitian ini adalah peneliti sendiri dengan menggunakan instrumen bantu seperti pedoman wawancara, pedoman observasi dan pedoman dokumentasi terstruktur berdasarkan dengan model evaluasi yang digunakan. Pedomanpedoman tersebut dibuat sendiri oleh peneiti.

Analisis data yang digunakan dalam penelitian ini adalah analisis interaktif model dari Miles \& Hiberman yang diperoleh dari hasil pengumpulan data seperti teknik observasi, wawancara, dan dokumentasi. Analisis data yang digunakan dalam penelitian ini adalah analisis interaktif model dari Miles \& Hiberman.

\section{HASIL DAN PEMBAHASAN}

\section{Evaluasi Jangka Panjang Program PKM}

Dampak jangka panjang merupakan hasil tertinggi dari program yang sudah dilaksanakan (International Federation of Red Cross and Red Crescent Societies, 2002, p.4). Dalam hal ini, dampak jangka panjang dari program PKM adalah peningkatan kualitas hidup masyarakat dalam rangka mengurangi pengangguran dan kemiskinan di Kabupaten Sleman (Kementerian Pendidikan dan Kebudayaan Republik Indonesia, 2014, p.1). Dampak jangka panjang yang sesuai dengan harapan telah dicapai oleh LKP Silia dan LKP Macell EC. Namun pada LKP Silia sudah sampai pada level merekrut karyawan, walaupun hanya karyawan freelance.

Berdasarkan hasil penelitian, dapat dilihat bahwa dampak jangka panjang telah berhasil dicapai oleh LKP Silia dan LKP Macell EC. Seluruh informan program PKM menyatakan bahwa kesejahteraan hidupnya membaik setelah berwirausaha di bidangnya masing-masing. Usaha yang dijalankan, memberikan penghasilan yang lebih baik daripada sebelumnya. Peserta di LKP Silia bahkan dapat merekrut karyawan pada saat mendapat pesanan jahitan dalam jumlah besar. Hal itu membuktikan bahwa pendidikan kewirausahaan memang dapat menambah daya tampung tenaga kerja, dan dapat menciptakan generator pembangunan lingkungan, bidang produksi, distribusi, kesejahteraan dan sebagainya (Alma, 2008, p.1).

Dari hasil evaluasi diketahui kreativitas memegang peran penting dalam pencapaian dampak jangka panjang. Nilai-nilai kewirausahaan yang harus dimiliki wirausahawan meliputi; commitment, confidence, cooperative, care, creative, challenge, calculation, communicatoins, competitiviness, change (Rohmat, 2016, pp.72-73). Kreativitas merupakan sumber penting dalam penciptaan daya saing untuk semua organisasi yang peduli terhadap growth (pertumbuhan) dan change (perubahan) (Hadiyati, 2011, p.10).

Fakta yang ditemukan di lapangan menunjukkan bahwa peserta program PKM di LKP Silia memiliki kreativitas yang dapat mempertahankan usahanya di tengah banyaknya persaingan. Kreativitas yang dimiliki peserta menjadikan banyaknya pelanggan yang mempercayainya. Banyaknya pelanggan ini membuat peserta memerlukan untuk merekrut karyawan yang secara tidak langsung dapat mengurangi jumlah pengangguran di Kabupaten Sleman.

Berbeda dengan peserta program PKM di LKP Macell EC. Peserta umumnya hanya berusaha untuk mensejahterakan kehidupannya sendiri. Hal ini diakui peserta terjadi karena modal usaha yang dimilikinya masih kurang untuk menjalankan usaha service handphone yang baik, sehingga penghasilan yang diperoleh peserta habis untuk biaya modal dan tidak tersisa untuk menggaji karyawan. Peserta juga mengaku pengetahuan dan keterampilan yang diperolehnya tidak dapat digunakan dikarenakan tidak sesuai dengan kondisi usaha teknisi handphone saat ini. Namun, peserta program PKM di LKP Macell EC memiliki inisiatif untuk mengatasi permasalahan yang dihadapinya. Peserta belajar mandiri melalui internet untuk 
memperbaharui pengetahuan dan keterampilannya dalam menjalankan usaha service handphone. Hal ini menunjukkan peserta masih memiliki motivasi yang tinggi dalam berwirausaha di bidang teknisi handphone.

Logical Framework melihat atau mengidentifikasi hubungan kausal antar komponen (Hall, 2014, p.8). Seluruh peserta pada LKP Silia mengungkapkan bahwa dampak jangka panjang yang diraihnya merupakan akibat dari penggunaan ketrampilan dan pengetahuan yang didapatkan pada proses pembelajaran. Hal yang berbeda terlihat pada LKP Macell EC, seluruh peserta mengakui bahwa dampak jangka panjang yang diraihnya merupakan akibat dari motivasi yang tinggi untuk berwirausaha. Maka dari itu dapat ditarik sebuah kesimpulan bahwa hubungan kausal terjadi pada LKP Silia dan tidak terjadi di LKP Macell EC.

Dari hasil evaluasi diketahui bahwa program PKM bukan merupakan satu-satunya faktor untuk mengurangi jumlah pengangguran. Terdapat faktor lain yang menjadi penentu, yaitu motivasi untuk berwirausaha. Motivasi berkaitan dengan niat dan tindakan pengusaha, dan motivasi juga berhubungan dengan kinerja pengusaha (Carsrud, \& Brännback, 2011, p.12). Seluruh peserta memiliki motivasi berwirausaha yang tinggi, hal ini menjadikan peserta memiliki kemauan keras untuk mencari pengetahuan melalui internet dan sumber pengetahuan lainnya.

\section{Evaluasi Outcome Program PKM}

Outcome adalah tujuan pelaksanaan program yang sudah dilaksanakan (International Federation of Red Cross and Red Crescent Societies, 2002, p.4). Dalam hal ini, outcome program PKM adalah setiap lulusan kursus dan pelatihan diharapkan dapat berusaha mandiri atau menciptakan lapangan kerja baru, menghasilkan produk barang dan/atau jasa yang kreatif serta inovatif sesuai dengan bidang kursus (Kementerian Pendidikan dan Kebudayaan Republik Indonesia, 2014, p.1). Outcome program yang sesuai harapan berhasil dicapai oleh LKP Silia, namun tidak berhasil dicapai oleh LKP Macell EC.

Berdasarkan hasil penelitian, outcome program telah berhasil dicapai oleh LKP Silia.
Faktor utama keberhasilan outcome adalah kontribusi softskill dan hardskill peserta. Utomo (2012, p.97) memaparkan bahwa softskill merujuk kepada indikator seperti kreativitas, sensitifitas, intuisi yang lebih terarah pada kualitas personal yang berada di balik perilaku seseorang, sedangkan hardskill menggambarkan perilaku dan keterampilan yang dapat dilihat mata (eksplisit). Apabila dilihat dari materi pembelajaran program PKM di LKP Silia, keterampilan menjahit merupakan hardskill yang diajarkan, dan pengetahuan wirausaha merupakan softskill yang diajarkan. Kedua keterampilan tersebut sesuai dengan yang peserta butuhkan untuk merintis usaha menjahit. Pachauri dan Aruna (2014, p.22) mengatakan "Softskills complement hardskills which are the technical requirements of a profession". Pernyataan ini didukung oleh Cimatti (2015, p.99) yang mengatakan "Softskills give Hardskills the required plasticity to develop and keep up to date in changing circumstances". Kedua pernyataan tersebut menekankan bahwa softskill melengkapi hardskill yang dimiliki peserta, dengan softskill yang baik, artinya peserta akan mampu mengembangkan keterampilan menjahit yang mereka miliki dan mempertahankannya di tengah perubahan situasi.

Modal usaha yang diterima peserta program PKM di LKP Macell EC belum mencukupi untuk membuka usaha di bidang teknisi handphone. Peserta hanya mendapatkan seperangkat alat service dasar, sedangkan masih banyak peralatan dasar lainnya yang perlu dimiliki peserta untuk menjalankan usaha teknisi handphone. Hal ini diakui para peserta menghambat usahanya. Peserta pada akhirnya sedikit demi sedikit mengumpulkan modal untuk membeli peralatan yang dibutuhkan.

Logical framework merupakan fondasi penting bagi evaluator untuk memahami apakah dan dengan cara apa program tersebut dapat berjalan dengan efektif, apakah program tersebut benar-benar menghasilkan outcome yang dapat terlihat dan apakah outcome tersebut sesuai dengan output program (McDavid, Huse, \& Hawthorn, 2018). Peserta pada LKP Silia mengakui bahwa outcome yang dihasilkanya merupakan akibat dari 
output yang baik, yaitu pengetahuan yang dikuasai di output sesuai dengan kebutuhan saat berwirausaha. Hal tersebut berbeda dengan yang dikatakan oleh seluruh peserta pada LKP Macell EC. Peserta mengakui bahwa pengetahuan dan ketrampilan yang digunakan dalam berwirausaha bukan berasal dari output dari program PKM.

\section{Evaluasi Ouput Program}

Output merupakan produk langsung dari kegiatan program dan bisa saja termasuk tipe, tingkat, dan target layanan yang akan diberikan oleh program (Kellogg, 2004, p.2). Dalam hal ini, output program PKM adalah peserta memiliki bekal keterampilan di bidang produksi barang/jasa, memiliki bekal pengetahuan kewirausahaan, serta memiliki pola pikir (mindset) dan sikap berwirausaha (Kementerian Pendidikan dan Kebudayaan Republik Indonesia, 2014, p.6). Output program yang sesuai harapan berhasil dicapai oleh LKP Silia, namun tidak berhasil dicapai oleh LKP Macell EC.

Berdasarkan hasil penelitian, output program yang diharapkan berhasil dicapai oleh LKP Silia. Materi, metode, jadwal dan penggunaan media yang baik menjadikan peserta mudah memahami pembelajaran yang disampaikan oleh tutor. Hal ini mengakibatkan peserta memahami materi menjahit, meskipun belum terampil, peserta memperoleh pengetahuan wirausaha, peserta memiliki motivasi yang tinggi untuk berwirausaha.

Berbeda dengan LKP Silia, peserta program PKM di LKP Macell EC menguasai keterampilan teknisi handphone yang diajarkan, namun belum bisa menguasai pengetahuan kewirausahaan yang diajarkan. Porsi pemberian teori adalah $30 \%$ dan porsi pemberian praktik adalah 70\%. Peserta mengakui bahwa porsi pemberian materi kewirausahaan dilaksanakan sebagai pelengkap kursus, sehingga materi kewirausahaan yang disampaikan tidak mampu diserap dengan baik oleh peserta, khususnya mengenai materi manajemen usaha. Sebelumnya diketahui bahwa LKP Macell EC tidak mencapai outcome dan output program. Pada pendidikan orang dewasa keberhasilan output sangat ditentukan oleh proses belajar. Bagaimana- pun juga proses belajar adalah proses yang terjadi pada internal diri seseorang dan tidak tampak secara lahiriah (Suprijanto, 2012, p.40).

Hal lainnya yang menonjol dari output program adalah motivasi peserta yang sangat tinggi untuk membuka usaha. Kedua lembaga, baik LKP Silia dan LKP Macell EC, memiliki peserta dengan motivasi berwirausaha yang tinggi. Semua peserta mengakui memiliki motivasi untuk membuka usaha setelah mendapatkan modal usaha dan keterampilan vokasional. Motivasi erat kaitannya dengan kemauan, dengan kemauannya, manusia mengadakan pengaturan diri terhadap badan dan kehidupan psikisnya. Kemauan tersebut bertindak sebagai pemersatu dari semua tingkah laku manusia yang mengkoordinasikan segenap fungsi kejiwaan menjadi bentuk kerja sama yang harmonis (Kartono, 2011, p.176). Menurut Rovijakkersd ada dua jenis motivasi, yaitu motivasi jangka panjang dan motivasi jangka pendek. Motivasi jangka panjang adalah keinginan untuk mendapatkan nilai yang baik, keinginan berprestasi dan sebagainya, sedangkan motivasi jangka pendek adalah minat untuk belajar pada saat itu saja (Suprijanto, 2012, p.41). Fakta yang ditemui dilapangan menunjukkan bahwa peserta program PKM di LKP Silia maupun LKP Macell EC memiliki motivasi jangka panjang.

Logical Framework digunakan karena ingin memeriksa konsistensi hubungan logis yang ada untuk mencapai tujuan program (Barau \& Olukosi, 2011, p.26o). Konsistensi hubungan logis dalam output dan proses terlihat pada program yang dilaksanakan oleh LKP Silia, yaitu output tercapai diakibatkan oleh proses yang sesuai dengan indikator keberhasilan. Hal lain terlihat pada LKP Macell EC, yaitu output tidak tercapai yang dikarenakan oleh ketidaksesuaian antara proses yang dilakukan dengan indikator keberhasilan.

\section{Evaluasi Proses Program PKM}

Proses dalam logical framework merupakan apa yang program lakukan terhadap input; yakni aktivitas, peralatan, kejadian, teknologi dan tindakan yang disengaja, yang merupakan bagian dari implementasi prog- 


\section{JPPM (Jurnal Pendidikan dan Pemberdayaan Masyarakat), 5 (2), 2018 - 103 \\ Arif Wijayanto, Iis Prasetyo}

ram (Kellogg, 2004, p.3). Dalam hal ini, proses program PKM terdiri dari aktivitas belajar mengajar (teori dan praktik), model, metode dan materi pembelajaran, penggunaan media pembelajaran, evaluasi hasil belajar, dan pendampingan rintisan usaha (Kementerian Pendidikan dan Kebudayaan Republik Indonesia, 2014, pp.17-21).

Berdasarkan hasil penelitian materi pembelajaran yang disampaikan peserta di LKP Silia dan LKP Macell EC adalah materi vokasional dan materi kewirausahaan yang disampaikan secara terpisah. Materi vokasional yang disampaikan pada LKP Silia adalah materi menjahit level 1-4, sedangkan materi vokasional yang disampaikan di LKP Macell EC adalah materi teknisi handphone hardware dan software. Materi kewirausahaan yang disampaikan adalah pola pikir wirausaha, sikap wirausaha dan manajemen usaha termasuk di dalamnya cara membuat perencanaan usaha dan administrasi usaha. Materimateri tersebut disusun sesuai kurikulum yang terdapat pada petunjuk teknis penyelenggaraan program PKM, agar tujuan pembelajaran dapat tercapai dengan tepat. Hal ini sesuai dengan tujuan pembuatan materi pembelajaran yaitu: (1) menyediakan bahan ajar yang sesuai dengan tuntutan kurikulum dengan mempertimbangkan kebutuhan peserta didik, lembaga, dan daerah, (2) membantu peserta didik memperoleh materi pembelajaran, (3) memudahkan tutor untuk menyampaikan pembelajaran (Departemen Pendidikan Nasional Republik Indonesia, 2008, p.10).

Anwar (2006) menjelaskan materi kewirausahaan pada pendidikan non formal dapat disajikan dalam dua pola. Pertama, Pola terintegrasi, yang penyelenggaraannya terinteg-rasi dengan bahan belajar keterampilan kejuruan. Kedua, pola terpisah atau khusus, yaitu diberikan secara khusus dalam satu paket keterampilan atau satu paket kursus secara khusus (Suherman, 2010, p.145). Apa-bila dilihat dari pelaksanaan program PKM di kedua lembaga, LKP Silia dan LKP Macell EC menggunakan pola pelaksanaan pembelajaran kewirausahaan secara terpisah. Pendidikan kewirausahaan terpisah ini diselenggarakan setelah peserta kursus menguasai seperangkat kemampuan vokasio- nal. Mereka membutuhkan kemampuan tambahan untuk menjual kemampuan itu sehingga bisa menghasilkan uang. Pada situasi ini, bahan belajar tentang kewirausahaan disajikan secara positif atau terlihat sebagai bahan belajar definitif.

Penggunaan media pembelajaran di LKP Silia berlangsung sesuai dengan harapan. Media pembelajaran yang disediakan (teorti maupun praktik) tersedia dalam kondisi yang baik dan mendukung berjalannya pembelajaran. Penggunaan media pembelajaran ini sebagai alat bantu dalam proses pembelajaran, sebagai komponen dari sub sistem pembelajaran, sebagai pengarah dalam pembelajaran, sebagai alat untuk membangkitkan perhatian dan motivasi peserta didik, meningkatkan hasil dan proses pembelajaran, mengurangi terjadinya verbalisme, mengatasi keterbatasan ruang, waktu tenaga dan daya indera (Rusman, 2012, p.162). Berbeda dengan LKP Silia, penggunaan media pembelajaran di LKP Macell EC tidak berlangsung sesuai harapan. Pada pelaksanaan pembelajaran hardware, media handphone yang digunakan adalah handphone yang mati total (rusak). Sehingga peserta hanya mengetahui cara membongkar handphone saja, tanpa tahu tindakan yang telah dilakukannya tersebut sudah benar atau belum benar, karena handphone sama sekali tidak bisa digunakan.

Setelah semua materi disampaikan, penyelenggara program, baik LKP Silia maupun LKP Macell EC mengadakan evaluasi hasil belajar peserta. Evaluasi ini dilakukan untuk mengetahui sejauh masa pengetahuan yang telah peserta dapatkan selama program PKM dilaksanakan. Selain itu, hasil evaluasi ini akan digunakan untuk pertimbangan pelaksanaan program yang akan datang. Sesuai dengan yang telah disamaikan oleh Ratnawulan \& Rusdiana (2014, p.70), bahwa evaluasi hasil belajar adalah upaya atau tindakan untuk mengetahui sejauh mana tujuan yang telah ditetapkan itu tercapai atau tidak, dengan kata lain, evaluasi hasil belajar berfungsi sebagai alat untuk mengtahui keberhasilan proses dan hasil belajar peserta didik.

Dari pemaparan tersebut, proses pelaksanaan program PKM di LKP Silia berjalan sesuai harapan, karena aktifitas yang 
dilaksanakan disesuaikan dengan kebutuhan para peserta, sehingga seluruh aktivitas yang dilakukan mendukung proses pembelajaran. Hal tersebut sesuai dengan pemaparan Suryono \& Entoh (2008, p.28) yang menyatakan bahwa segenap aktifitas pendidikan nonformal selalu didasarkan pada upaya pengembangan sumber daya manusia. Disisi lain, proses pelaksanaan program PKM di LKP Macell EC belum sesuai harapan. Hal tersebut dikarenakan dalam penggunaan media pembelajaran di LKP Macell EC belum maksimal, akibatnya peserta tidak percaya diri dan mengalami kebingungan terhadap materi yang diajarkan. Proses yang dicapai oleh LKP Silia maupun LKP Macell EC tidak lepas dari input yang ada pada program. Hal tersebut dapat dilihat bahwa proses yang berhasil dicapai oleh LKP Silia merupakan akibat dari input yang baik sedangkan ketidaktercapaian proses pada LKP Macell merupakan akibat dari input yang kurang memadai

\section{Evaluasi Input Program PKM}

Input dalam logical framework merupakan sumber keuangan, manusia, dan sumber daya material yang diperlukan untuk melakukan suatu kegiatan (International Federation of Red Cross and Red Crescent Societies 2002, p.4). Dalam Hal ini, Input yang diperlukan dalam melaksanakan program antara lain: (1) Lembaga penyelenggara program profesional dan kompeten dibidangnya, (2) Peserta program memenuhi pra syarat program PKM, (3) Tutor/tenaga pengajar adalah seorang yang ahli dibidang kursus, (4) Sarana dan prasarana sesuai dengan kebutuhan program pembelajaran untuk mendukung tercapainya tujuan program, (5) Dana program PKM sesuai dengan kebutuhan program (Kementerian Pendidikan dan Kebudayaan Republik Indonesia, 2014, pp.10-17).

Berdasarkan hasil penelitian, diketahui bahwa penyelenggara program di kedua LKP sudah profesional dan kompeten di bidangnya, sehingga mampu menciptakan wirausahawan baru yang siap merintis usaha. Hal tersebut sesuai dengan pernyataan Suryono \& Sumarno (2012, p.114) yang menyatakan bahwa lembaga penyelenggara program yang profesional mampu membantu merintis berbagai inkubator bisnis, sehingga warga belajar mampu memanfaatkan kesempatan untuk belajar berwirausaha.

Dalam hal ini lembaga penyelenggara program PKM, baik LKP Silia maupun LKP Macell EC mampu mendayagunakan seluruh sumber daya yang ada untuk pelaksanaan program, merencanakan proses pembelajaran dengan membuat jadwal pembelajaran yang jelas dan sistematis, dan berkomunikasi secara teratur dengan pemangku kepentingan, staf, peserta dan masyarakat. Hal ini sesuai dengan apa yang dijelaskan Kamil (2010, p.46) mengenai kompetensi yang harus dimiliki penyelenggara program untuk meningkatkan mutu layanan, yaitu: mampu menjabarkan sumber daya yang ada untuk menyediakan dukungan yang memadai bagi tenaga pendidik (tutor), bahan pembelajaran yang cukup, dan pemeliharaan fasilitas yang baik.

Peserta program memenuhi prasyarat program. Peserta program PKM di LKP Silia, sebelum mengikuti program umumnya memang telah terlibat di bidang menjahit ataupun usaha busana yang terkait dengan kegiatan menjahit. Peserta umumnya telah memiliki pengalaman menjadi karyawan di usaha busana milik orang lain. Peserta mengaku tertarik dengan bidang menjahit. Hal tersebut mempermudah proses pembelajaran. Demikian pula dengan peserta program PKM di LKP Macell EC. Peserta umumnya telah bekerja sebagai karyawan di usaha service handphone milik orang lain. Tanpa keahlian tersebut, peserta akan mengalami kesulitan kerja, yaitu harus selalu bergantung kepada orang lain dan harus selalu mengeluarkan biaya yang lebih.

Input selanjutnya adalah tutor program. LKP Silia memiliki tutor yang kompeten di bidang menjahit dan bidang kewirausahaan, serta mampu membimbing dan memotivasi peserta didik. Tutor program PKM di LKP Macell EC hanya kompeten di bidang teknisi handphone, LKP Macell EC belum memiliki tutor yang kompeten di bidang kewirausahaan. Disini, penyelenggara perlu memperhatian pemilihan tutor. Pada tahap pemilihan tutor untuk pendidikan orang dewasa, Tough menyatakan bahwa kompetensi saja tidak cukup. Seorang tutor yang baik harus mampu 
membimbing dan memotivasi agar membantu peserta didik untuk dapat mengarahkan dirinya dalam belajar (Suprijanto, 2012, P.48).

Selanjutnya adalah sarana dan prasarana yang tersedia untuk pelaksanaan program. LKP Silia telah menyediakan sarana dan prasarana yang mendukung proses pembelajaran. Mesin jahit yang tersedia sesuai dengan jumlah peserta, kain dan peralatan jahit lainnya sudah disediakan pihak penyelenggara dalam kondisi baik. Sedangkan pada LKP Macell EC, sarana dan prasarana yang tersedia kurang menunjang proses pembelajaran, terutama pada media untuk materi hardware. Handphone yang digunakan adalah handphone yang mati total, sehingga peserta tidak tahu apakah tindakan yang sudah dilakukan untuk memperbaiki handphone tersebut sudah tepat atau belum.

Mengukur cost effectiveness dan cost efficiency merupakan tujuan dari dilaksanakannya evaluasi program (Wirawan, 2012, p.12). Pada LKP Silia dapat diketahui bahwa cost effectiveness dan cost efficiency sesuai dengan program yang dilaksanakan sedangkan pada LKP Macell EC cost effectiveness tidak tercapai karena modal yang diberikan tidak sepadan dengan tujuan program PKM.

Masalah pendanaan pada penyelenggaraan pendidikan nonformal memang masih menjadi kendala tersendiri. Alokasi anggaran pada seluruh tingkatan pemerintahan di banyak negara bagi penyelenggara pendidikan non formal terutama pada pendidikan orang dewasa umumnya sangatlah minim apabila dibandingkan dengan alokasi anggaran pendidikan formal. Tak hanya terkait pemenuhan sarana prasarana, pendanaan yang minim akan berdampak pada keluasan cakupan/ akses masyarakat kepada penyelenggara pendidikan, gaji, serta ketersediaan fasilitator yang kompeten (Hussain, 2013, pp.141-142).

\section{SIMPULAN}

Dampak jangka panjang telah dicapai oleh LKP Silia dan LKP Macell EC. Pada LKP Silia, peserta program PKM di LKP Silia mampu mensejahterakan kehidupannya sendiri dan orang lain dengan berwirausaha di bidang menjahit. Dampak jangka panjang yang dicapai oleh LKP Silia tersebut disebabkan oleh outcome program yang telah dicapai sebelumnya. Begitu pula pada LKP Macell EC menunjukkan peserta bisa mensejahterakan kehidupannya sendiri dengan cara berwirausaha. Namun, dampak jangka panjang yang dicapai oleh LKP Macell EC bukan disebabkan oleh outcome yang ditentukan program, melainkan berasal dari motivasi peserta untuk mempelajari keterampilan dan pengetahuan wirausaha secara mandiri melalui internet dan modal usaha milik peserta.

Outcome program berhasil dicapai oleh LKP Silia, namun tidak berhasil dicapai oleh LKP Macell EC. Peserta program PKM di LKP Silia mampu menggunakan keterampilan menjahit, pengetahuan dan sikap wirausaha serta modal usaha berupa mesin jahit untuk merintis usaha menjahit. Outcome yang dicapai oleh LKP Silia didapatkan dari program yang terdapat dalam hierarki logis. Outcome program tidak berhasil dicapai oleh LKP Macell EC. Peserta tidak menggunakan keterampilan yang didapatkan saat mengikuti program dikarenakan keterampilan tersebut tidak sesuai dengan kebutuhan di lapangan. Ketidak tercapaian outcome program ini disebabkan oleh output program yang tidak sesuai dengan kebutuhan peserta dalam merintis usaha di bidang teknisi handphone.

Output program berhasil dicapai oleh LKP Silia namun tidak berhasil dicapai oleh LKP Macell EC. Setelah program PKM selesai dilaksanakan, Peserta program PKM di LKP Silia memiliki keterampilan menjahit, memiliki pengetahuan berwirausaha dan memiliki motivasi berwirausaha yang tinggi. Output program yang dicapai oleh LKP Silia disebabkan oleh proses program yang dilaksanakan dengan baik. Output program pada LKP Macell EC tidak memenuhi kriteria keberhasilan program. Peserta menguasai teknik dasar memperbaiki handphone dan memiliki motivasi berwirausaha yang tinggi, namun tidak menguasai pengetahuan kewirausahaan yang telah diajarkan. Output program yang tidak dicapai oleh LKP Macell EC disebabkan oleh proses program yang dilaksanakan dengan kurang maksimal.

Proses program yang dilaksanakan LKP Silia menunjukkan bahwa aktivitas yang dilakukan selama program berlangsung jelas 


\section{JPPM (Jurnal Pendidikan dan Pemberdayaan Masyarakat), 5 (2), 2018 - 106 \\ Arif Wijayanto, Iis Prasetyo}

dan terstruktur. Model dan metode pembelajaran sesuai dengan kondisi peserta. Penggunaan media pembelajaran sesuai dan mendukung proses pembelajaran. Materi pembelajaran keterampilan menjahit dan kewirausahaan sesuai dengan juknis program. Di akhir pelaksanaan program pendidikan kewirausahaan dilaksanakan evaluasi hasil belajar peserta didik. Penyelenggara program mendampingi peserta program PKM selama 3 bulan dengan cara mendatangi lokasi usaha milik peserta, Proses ini dapat terlaksana sesuai dengan kriteria keberhasilan program karena input program yang telah memenuhi pra syarat program. Proses program yang dilaksanakan LKP Macell EC menunjukkan bahwa aktivitas yang dilakukan selama program berlangsung jelas dan terstruktur. Model dan metode pembelajaran sesuai dengan kondisi peserta. Penggunaan media kurang maksimal dan kurang mendukung proses pembelajaran. Materi yang dilaksanakan oleh LKP sillia adalah materi tentang service handphone tetapi tidak terdapat materi tentang kewirausanaan. Penyelenggara program mendampingi peserta program PKM selama 3 bulan dengan cara membuka konsultasi tanpa batas. Proses program yang terlaksana pada LKP Macell EC tidak sesuai dengan kriteria keberhasilan program. Hal ini disebabkan oleh input program yang belum memenuhi pra syarat program.

Input yang sesuai dengan prasyarat program telah dicapai oleh LKP Silia, namun tidak berhasil dicapai oleh LKP Macell EC. Pada LKP Silia, penyelenggara program layak melaksanakan program, tutor berkompeten di bidang menjahit dan kewirausahaan, peserta sesuai dengan kriteria program, sarana dan prasarana menunjang keterlaksanaan progran dan dana mencukupi untuk pelaksanaan program. Sedangkan Input program LKP Macell EC belum memenuhi prasyarat program, dikarenakan tutor, sarana dan prasarana serta dana belum memenuhi syarat untuk pelaksanaan program. Dana yang didapatkan oleh LKP Macell EC mencukupi untuk menjalankan proses pembelajaran tetapi tidak mencukupi untuk membuka usaha bagi peserta.

\section{DAFTAR PUSTAKA}

Alma, B. (2008). Kewirausahaan. Bandung: Alfabeta

Anwar, M. (2006). Pendidikan kecakapan hidup (life skills education). Bandung: Alfabeta.

Anyadike, N. (2012). Entrepreneurship development and employment generation in Nigeria: problems and prospect. Journal of Education and General Studies, 1(4), 88-98

Badan Pusat Statistik Daerah Istimewa Yogyakarta. (2016). Berita Resmi Statistik. Diunduh pada tanggal 5 September 2016, dari https://yogyakarta.bps.go.id/website/b rs_ind/brsInd-20160504130754.pdf

Barau, D.A., \& J.O. Olukosi. (2011). Logical framework analysis (LFA): An essential tool for designing agricultural project evaluation. Nigerian Journal of Basic and Applied Science. 19(2): 260-268.

Carsrud, A., \& Brännback, M. (2011). Entrepreneurial motivations: what do we still need to know?. Journal of Small Business Management, 49(1), 9-26.

Cimatti, B. (2015). Definition, development, assessment of soft skills and their role for the quality of organizations and enterprises. International Journal for Quality Research. 10(1) 97-130.

Departemen Pendidikan Nasional Republik Indonesia. (2008). Materi Pelatihan Kurikulum Tingkat Satuan Pendidikan, Jakarta: Dirjen Mapendamen

Hadiyati, E. (2011). Kreativitas dan inovasi berpengaruh terhadap kewirausahaan usaha kecil. Jurnal Manajemen dan Kewirausahaan. 13 (1), 8-16.

Hall, M. (2014). Evaluation logics in the third sector. VOLUNTAS: International Journal of Voluntary and Nonprofit Organizations, 25(2), 307-336.

Hussain, M.S. (2013). Challenges and emerging perspective in adult education delivery in Nigeria. European Scientific Journal. 9 (13), 25-31.

International Federation of Red Cross and Red Crescent Societies. (2002). 
JPPM (Jurnal Pendidikan dan Pemberdayaan Masyarakat), 5 (2), 2018 - 107

Arif Wijayanto, Iis Prasetyo

Guidelines for assessment in emergencies. Switzerland: ICRC dan International Federation of Red Cross and Red Croscent Societies.

Kartono, K. (2011). Patologi sosial: Gangguangangguan kejiwaan. Jakarta: PT Raja Grafindo Perkasa.

Kellogg, W. K. (2004). Using logic models to bring together planning, evaluation, and action: logic model development guide. Michigan: Kellog Foundation.

Kementerian Pendidikan dan Kebudayaan Republik Indonesia. (2014). Petunjuk teknis program pendidikan kewirausahaan masyarakat. Jakarta; Kemendikbud

Khalifa, A.H. \& Diaf, M. (2016). The impact of entrepreneurship education on entrepreneurial intention: the uae context. Polish Journal Of Management Studies. 14 (1), 119-128.

McDavid, J. C., Huse, I., \& Hawthorn, L. R. (2018). Program evaluation and performance measurement: An introduction to practice. Sage Publications.

Kamil, M. (2010). Pendidikan non formal pengembangan melalui pusat kegiatan belajar masyarakat (PKBM) di Indonesia. Bandung: Alfabeta.

Pachauri, D., \& Aruna Y. (2014). Importance of soft skills in teacher education programme. International Journal of Educational Research and Technology. 5 (1), 22-25.

Prasetyo, I. (2011). Pengembangan pembelajaran berbasis masalah untuk meningkatkan motivasi berprestasi warga belajar program pendidikan kecakapan hidup. Jurnal Ilmiah Visi. 6 (1)

Presiden Republik Indonesia. UndangUndang Republik Indonesia nomor 20 tahun 2003 tentang sistem pendidikan nasional, Pub. L. No. 20, UndangUndang Republik Indonesia 26 (2003). Indonesia.

Ratnawulan, E. \& Rusdiana (2014). Evaluasi pembelajaran. Bandung: Pustaka Setia
Rohmat, R. (2016). Penguatan nilai-nilai kewirausahaan dan pendidikan karakter bagi mahasiswa PAI IAIN Surakarta. SHAHIH: Journal of Islamicate Multidisciplinary, 1(2), 179192.

Rusman, R. (2012). Manajemen kurikulum. Jakarta: Rajagrafindo Persada

Sabri, S. (2013). Kewirausahaan (entrepreneurship) modal manusia dalam membangun perekonomian. Jurnal Ekonomika. 4 (7), 26-32

Septiarti, S. W., \& Mulyadi, M. (2007). Memaknai kembali peningkatan profesionalisme tenaga pendidik pendidikan nonformal. Jurnal Ilmiah Visi, 2(2), 21-27.

Suherman, E. (2010). Desain pembelajaran kewirausahaan. Bandung: Alfabeta.

Suprijanto, S. (2012). Pendidikan orang dewasa, Jakarta: Bumi Aksara

Suryono, Y., \& Entoh, T. (2016). Inovasi pendidikan nonformal. Yogyakarta: Graha Cendekia.

Suryono, Y., \& Sumarno. (2012). Pembelajaran kewirausahaan masyarakat. Yogyakarta: Aditya Media Publishing.

Suharyadi, A. N., Purwanto, S. K., \& Maman, F. (2007). Kewirausahaan (Membangun usaha sukses sejak usia muda). Jakarta: Salemba Empat.

Suparta, N., \& Ramantha, I.W. (2010). Manajemen bisnis kecil dan kewirausahaan. Denpasar: Pustaka Nayottama.

Utomo, H. (2012). Kontribusi soft skill dalam menumbuhkan jiwa kewirausahaan. Jurnal Ilmiah Among Makarti, 3(5).

Wirawan. (2012). Evaluasi teori model standar aplikasi \& profesi: Contoh aplikasi evaluasi program. Jakarta: Rajawali Pers.

Zidane, Y. J., Johansen, A., Hussein, B. A., \& Andersen, B. (2016). PESTOLFramework for «project evaluation on strategic, tactical and operational levels». International Journal of Information System and Project Management, 4(3), 25-41. 